\title{
E-LEARNING AS A TRAINING TOOL FOR CIVIL SERVANTS: A CASE IN THE STATE OF PARANA - BRAZIL
}

\author{
Adriano STADLER \\ Federal Institute of Parana \\ Curitiba, Brazil \\ Rosi Teresinha Munaretti de CAMARGO \\ Federal Institute of Parana \\ Curitiba, Brazil \\ Marcos Rogerio MAIOLI \\ Federal Institute of Parana \\ Curitiba, Brazil
}

\section{ABSTRACT}

The distance education (DE) modality evolves as new Information and Communication Technologies (ICT) are developed and based on the methodologies that are being used in the media dissemination of information, educational institutions and organizations take ownership of these innovations to promote their teaching processes. One of the methods that have achieved prominence is how e-learning, which is also called educational computer or online education, is conducted by the internet - synchronously or asynchronously, eliminating the figure of the pedagogical mediator in real time. This article aims to answer the main question: What is the perception of Parana civil servants, which undertake the distance e-learning methodology post-graduate programs in relation to the use of technologies and materials. The surveys of the study were $\mathbf{6 7 0}$ civil servants from Parana state, students of the post-graduation basis course in Public Management in elearning methodology, which stems from Parana State Government's partnership with a federal institution of vocational and technological education. The research was conducted by using qualitative and quantitative approach, descriptive and questionnaire application method survey, containing 12 closed questions. The main results show that there is high familiarity and acceptance to e-learning. On the other hand, the use of teaching materials evidenced conservatism and attachment to printed learning materials, highlighting the printed book as a key to distance learning.

Keywords: Distance education, professional training, e-learning.

\section{INTRODUCTION}

From the advent of globalization and popularization of real-time communication brought out by the Internet, a range of new business came on the market, providing new jobs, new methods of work, job training, facilitated accessibility, possibilities of new learning modalities and forms of formal and continuing education. Thus, distance education is gaining ground and it provides the most diverse social groups access to education with the use of information and communication technologies, eliminating social barriers (Ferreira, 2009). It allows to benefit those individuals who do not have access to mainstream education, and those who are distant from the educational centers in quite remote or isolated locations (Ikeda and Knight, 2005) and by choosing this methodology for learning, turning it into a more competitive society (Salvucci, Lisbon and Mendes, 2012). 
Distance learning has evolved from experience gained over the years in the semi-presential model, already established in professional, technical, higher and post-graduate courses, so as to make it more contemporaneously, the e-learning methodology has emerged, by justifying whether the mobility and autonomy that students have on the accomplishment of their studies, thus easing the access to education for those students who do not have the time to tele-presence lessons in loco. Likewise, access to e-learning to offer innovation and add value to knowledge, given that this tool has become popular for conducting training, courses and other activities in which real-time education is not possible.

The distance education in Brazil is a reality, and it has achieved continuous growth in enrollment form, as shown by the results of the Brazilian Association of Distance Education ABED (2016) from 2014 to 2015 (The Census Distance Education Learning Analytical Report in Brazil (EAD.BR), currently in its $7^{\text {th }}$ edition is the effort to understand the education scenario the distance learning in Brazil and offer a mapping of the key trends in the sector related to the segments and to the academy). This growth in distance education enrollments occurred in blended forms and e-learning (online) by $25 \%$ strengthening even more, this kind of education by obtaining users.

In addition to the private institutions these new forms of educational opportunities and learning public institutions are also being developed, including the Federal Institute of Parana (IFPR) which is following the worldwide trend of expansion of distance courses, offering courses in various levels, including graduate courses, which is the objective of this research. Since its creation by the Law number 11.892, of December 29th, 2008, the IFPR provides education in basic, technical and technological levels, but this study deals only with students of the post-graduate degree in Public Management, which had the opportunity to study it by using the e-learning modality as a result of a partnership between the IFPR and the Government of the State of Parana through its Secretariat for Administration and Security, which administers the School of the State Government, Secretary for Urban Development (SEDU). The post-graduation basis course was offered to government civil servants (also called by public servants or public workers) from 399 municipalities in Parana State.

This partnership was designed by thinking about the difficulty in empowering the state and the municipal civil servants to carry out some functions in public administration, given the large number of people who are unable to access a higher institution in a classroom mode, for reasons such as the distance of their residences to the educational institution, downtime due to hours of work, family issues and inadequate factors related to this methodology. In the first stage of the project objective was to train, at the level of expertise in the specialization, 1257 state and municipal civil servants.

Seeking with this study, to check with the workers of a public sector of the post-graduate course in Distance Education Public Management of IFPR, as they evaluate the progress in addressing the use of technology and its acceptance on the practiced methodology and how this public is receptive to new learning modalities.

\section{THEORETICAL BASE}

From the idea that education is a civil right, several types of education are now reflected in the society as a way to promote access to knowledge, especially in formal education. In this context, distance education (DE) has increasingly occupied space by democratizing this access. Thus "the adoption of distance education must be accompanied by training and theoretical and practical reflections." (Vilaca, 2011: 2). Similarly, this method "takes on a key role as a learning format by eliminating social barriers, and expanding the development of citizens at various levels by making learning more flexible" (Ferreira, 2009:53).

The distance education (DE) in Brazil had its establishment by Article 80 of the Law No. 9.394, regulated by the Decree No. 5.622, of December 19th, 2005, which in Article 1 is conceptualized as: 
Characterized distance education as an educational modality in which the didactic-pedagogic mediation in teaching and learning processes occur with the use of media, information and communication technologies, with students and teachers who are developing educational activities in several different places or times. (Brazil, 2005, p.1).

It is observed that the concept that guides the distance education in Brazil has some characteristics that are distinct from the traditional presencial classes, as it appears to have important points that distinguish this modality. In relation to how learning is designed and implemented, it is emphasized that it has its own characteristics, but should not be seen as antagonistic to traditional modality, but they are analyzed from their particularities. In the distance learning process, it is developed in virtual spaces and the school is not just the place where you teach, but it happens to be the place where students learn by themselves, under the guidance of teachers and tutors. The learning by the new generation becomes an opportunity by offering tools to the subjects so that they develop for themselves the application of theory in practice, which they are usually in contact with.

Encouraging aspects which lead to e-learning to occupy even more space in a growing society and demand for competent professionals who are capable of disputes in academic and industrial sectors, it is pertinent to the thought of Levy: "Through virtual worlds, we cannot only exchange information but truly think together, to set our memories and projects in common to produce a cooperative brain." (Levy, 1998:96).

Based on this assumption, education becomes mediated by individuals who, by the use of machines, distribute and receive content through technological networks, being virtually together (synchronous model) or without interaction in real time (asynchronous model). This ability to interact each in their own time is one of the main features of the e-learning methodology. Its popularity in the distance is the result of technological advances, especially with the growth of the Internet generating profound effects such as, the distribution method of the content of education (Welsh et al., 2003).

The e-learning teaching modality can be conceptualized as a distance education model that combines various forms of synchronous and asynchronous communication by using dynamic interfaces with dialogue language and to arouse student interest in exploring the various learning objects that are gathered in a learning platform (Lima and Capitao, 2003). Its use is not restricted to the academic environment as an alternative to classroom learning, and it is a widespread form of professional training. Hairston and Nafukho (2011) present the advantages of using e-learning in organizations and companies. On the one hand, institutions derive cost savings in training programs as well as optimizing the logistics involved in trips and accommodations. On the other hand, for employees, it is a more flexible training schedule, thus expanding training opportunities and the acquisition of skills that, ultimately, it can add value to the organization.

In order to make e-learning methodology be used in an organization or institution, whether for continued corporative education or formal education, it is essential the existence of modern studios with audio and video capabilities for the production of classes. As well as, the existence of professionals with skills in handling equipment with sufficient technological capacity to store, retrieve and distribute data to users who are connected through videos, texts and other teaching resources of distance education in real time. Theoretically e-learning "is any kind of learning that has support from the Internet or Intranet (LAN or WAN) for distribution of contents, social interaction and learning support" (Lima and Capitao, 2003:37).

On the other hand, there must be space for collaboration and exchange of information among all the participants of education, which is one of the factors that made the social networks on the Internet one of the great innovations of the XXI century. This capability provides the necessary quality for dynamic language of this type of education. "This training method assumes that the initiative and management of the learning process are in 
the hands of the learner, without excluding external support from the professor/tutor (Fernandez, 2014:75). In distance education tutoring, it is directly related to the teaching and learning processes and resembles the teacher's role in the classroom and thus it occupies key space, and the student has the tutor figure as the voice for their demands.

The profile of the tutor of a distance learning course, in the conception of Belloni (2003) has some characteristics that are not related only to an objective competence but are required. They are aspects related to interpersonal relationships and to realize that the construction of knowledge takes place internally. Motivation is utterly important, but it is critical to build the knowledge along with the student. The tutor's role is to provide online support in mentoring the distance, mediating the process of teaching and learning through ICT, to carry out and set targets, track students via telephone reports and contacts (registered) so that they realize proximity in order to establish and maintain close interpersonal relationship, seeking to maintain the motivation for studies, interest in the training themselves, avoiding evasion and the disengagement of the students.

Lahm Jr. and Rader (2015) present the possibilities of e-learning, claiming that this method allows the cultivation of multiple skills and expands non-traditional knowledge within the study area. Thus, schools and teachers should take advantage of the technologies and insist on the development of platforms that merge the functionality of social networking with virtual learning platforms.

The Virtual Learning Environment (VLE) for e-learning is a tool where all learning resources such as videos, texts, audios, articles, chat, forums, case studies, exercises, interaction spaces and collaboration are stored, all of which have interface with the student by using language that encourages learning. The Virtual Learning Environment is a fertile space of meaning where students interact with the technical objects in the construction of knowledge, in the pursuit of learning (Lavigne et al., 2015). There are several forms of synchronous and asynchronous interaction, by using the VLE as a learning support, mediated or not by an online tutor. Standing out are electronic book, web radio, chats, forums, case studies, practical research, directed and evaluation activities. In addition to this platform, students can receive printed educational materials as a way of expanding learning opportunities (Malinovski et al., 2014).

As for printed teaching materials in distance education, Preti (2010) emphasizes the need to provide not only education, but also above all the author's interaction with the student through texts with technical quality and depth of information. The author also points out that learning strongly depends on the recognizing and interaction with the text, thus giving a great responsibility to the student by the learning process. The printed teaching materials are important educational resources, which are produced with the intention of teaching and interacting with the student and facilitating the construction of knowledge.

Finally, for the e-learning method is implemented effectively it is necessary to keep up with the technological changes and there adapt to their audiences. Halicki et. al., (2016) described the technological trajectory of the implementation of the "web based learning method" in a Brazilian public university. It turned out that the changes introduced by the information and communication technology in the educational sector and transposed to the daily practices of teachers and tutors were able to generate transformations in the sector. There was sensitivity of educational managers to perceive, adapt and deal with the potential of web based learning technology in relation to the claims and needs of students in relation to the teaching method.

\section{METHODS}

This article is characterized as a descriptive study and it is divided into two parts: a qualitative approach (secondary data available at the institution) and other quantitative approach (questionnaire administered to students). The main strategy used in this study was a questionnaire or survey, which, according to Yin (2001:24), does not require control 
over behavioral events and focuses on contemporary events. For the author, the form of the research questions "who, what, where, how and when" favors data collection strategies.

The variables in the questionnaires addressed concepts applicable methods of organizational learning through Information and Communication Technologies, for example, teaching resources, forms of interaction, knowledge mediation methods and assessment of learning. The research population is part of the students of the postgraduate course in Public Management IFPR, which is a federal education institution that offers technical, subsequent courses, technological undergraduate and graduate ones.

The secondary data collection began through literature review, which aims to, theoretically, support the present study. The questionnaire aimed to determine how public workers of Parana State evaluate the course in e-learning modality, relating to the use of technology and which its acceptance on this methodology is and to what extent this public is receptive to new learning modalities. As this questionnaire was based on an adjective scale with poles (Lickert's scale), it was possible to detect the intensity of the perception of the respondent. The results of the survey research were tabulated by using Microsoft Excel software, through simple tabulations and descriptive statistics about the issues pertaining to the questionnaire.

\section{Object Study Description}

In order to diagnose the student profile research, it was carried out with students of the post-graduation course in Public Management from the IFPR totaling 1257 students (who started the course) in 36 cities in the state of Parana - Brazil. There was a $22.4 \%$ dropout rate, totaling 975 students took part in the study sample. The number of respondents of the electronic form was 670 , which amounts to $68.7 \%$ of the total sample.

The courses at IFPR were created thanks to the existing educational demands for very different audiences. The IFPR offers post-graduation courses in two formats, one semipresential and another totally distance learning.

Synthetically, the IFPR e-learning modality offers students three ways of interacting with knowledge: 1-Printed textbook; 2-Virtual learning environment; 3-Tutoring. The IFPR modality seeks to achieve effectiveness in teaching by using the following strategies:

Table 1. Model e-learning IFPR

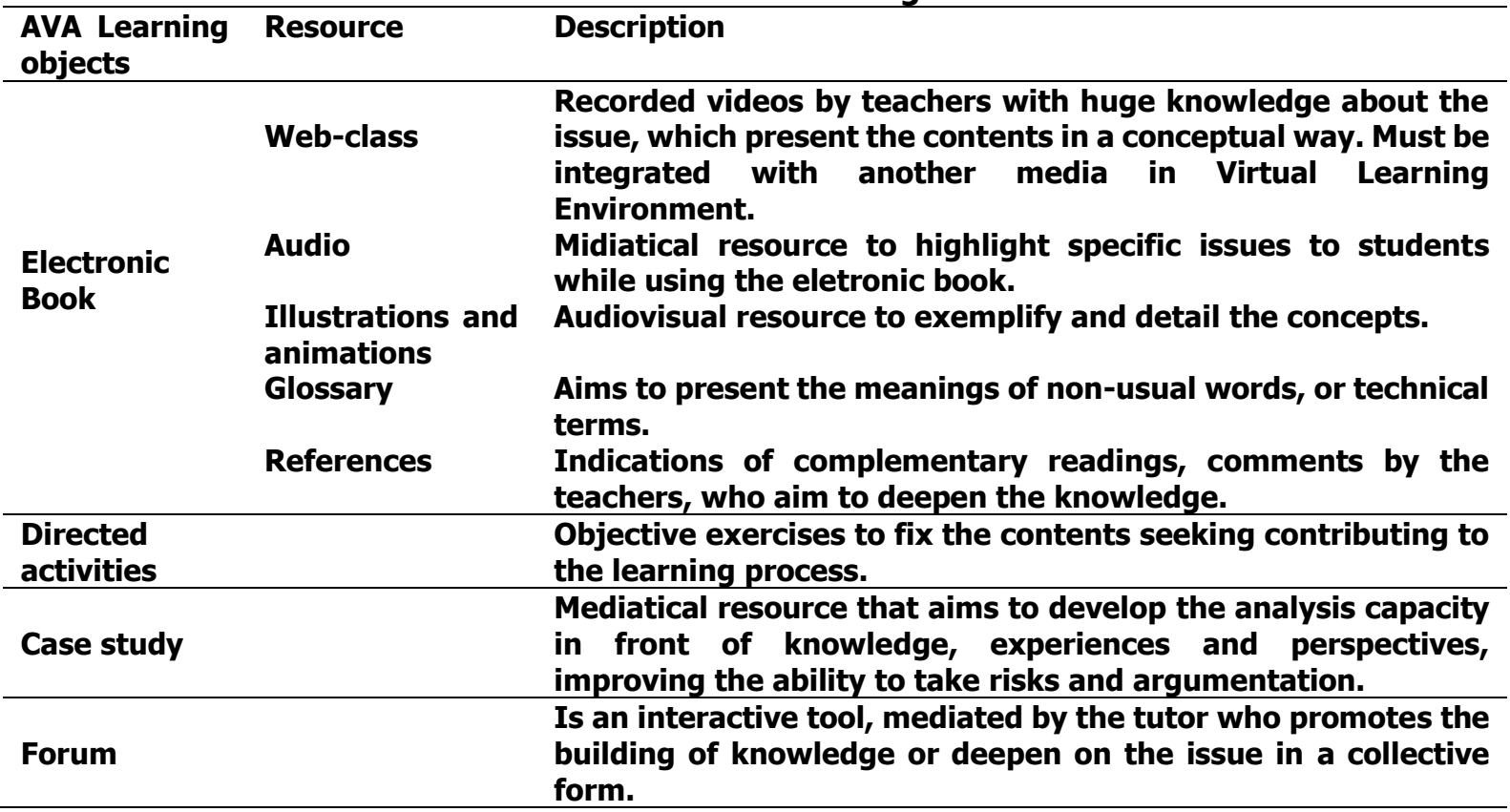




\begin{tabular}{ll}
\hline $\begin{array}{l}\text { Pratical } \\
\text { research }\end{array}$ & $\begin{array}{l}\text { The research of the context action is a must, thus the student } \\
\text { must kick off in the theory towards practice, and understands } \\
\text { how to apply specific content. }\end{array}$ \\
\hline web radio & $\begin{array}{l}\text { Their contents are related to courses and the discussion is } \\
\text { mediated by teachers and tutors. They still can be fulfilled by } \\
\text { synchronous form to the students, taking them to reflection } \\
\text { and discussion to the proposed subject. }\end{array}$ \\
\hline Chat & $\begin{array}{l}\text { Promote chats among the students and tutors on specific } \\
\text { subjects of the course. They can be scheduled previously and } \\
\text { mediated by the tutors. }\end{array}$ \\
\hline Evaluation & $\begin{array}{l}\text { Subjective and objective questions fulfilled with consult to the } \\
\text { didactical material by the student. }\end{array}$ \\
\hline
\end{tabular}

From the presented characterization, it is necessary to know the perception of civil servants of Parana as students of graduation course in Public Management which are offered by IFPR about ICT and effectiveness of e-learning as a professional training method.

\section{DATA ANALYSIS}

The survey was sent to students of the course via an electronic system, containing 12 closed questions involving the use of technology and methodology, enabling them to map the profile. Analyzing the profile of participants in relation to age, gender, marital status and family income, the following results are shown: $68 \%$ of the students are between 31 and 50 years (average $\mathbf{4 0 . 5}$ years), higher age group the average age of students presented by the MEC of Education Census/Inep of 2012, which states that the distance education this average is $\mathbf{3 1}$ years old. It is noteworthy that $11 \%$ of students are over $\mathbf{5 0}$ years old, which demonstrates the inclusive nature of distance education, especially for digital inclusion, given that students undertake all learning activities in the Virtual Learning Environment.

In relation to gender, it was found that $67 \%$ of the course students are women, a result that confirms the INEP data (2012), which shows that $56.1 \%$ of university students are female. Another important research finding is that $63 \%$ of the students are married or declared stable union. The predominant income group is between $R \$ 1,000.00$ and $R \$$ $3,000.00$ (Brazilian currency) per month, totaling $53 \%$ of respondents, which demonstrates that the student who seeks the DL does not have high income, and in this type of modality, due to the low cost one factor of inclusion. Yet in terms of income, we highlight the $9 \%$ of students with income below $R \$ 1,000.00$ and $13 \%$ with income above R \$ 5,000.00 (Brazilian currency).

This research also sought to know what was the student's prior familiarity with distance education, and what were their attitudes regarding the use of new technologies of communication and information. The result worth mentioning is that $63 \%$ of students had performed some distance course previously. However, the fact that stands out is that $49 \%$, nearly half, had studied with the e-learning methodology, i.e. teaching asynchronous models, using virtual learning environments as a teaching base, not depending solely on the presence support locations provided in the classic form of distance education. This fact indicates that the e-learning methodology is viable for continued training in the public sector.

When asked if they are adapted to this learning modality, the result shows that $7 \%$ are not suited, $22 \%$ do not agree or disagree, i.e., are neutral, and $72 \%$ totally agreed that are adapted to the methodology. Taking into account that the target audience are civil servants, aged 30-50 years old, this result is significant and demonstrates a shift in the distance education paradigm. 


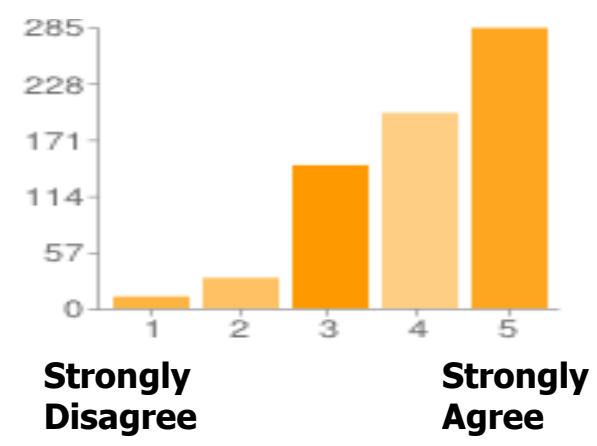

\begin{tabular}{|l|l|}
\hline 1 - Strongly Disagree & $2 \%$ \\
\hline 2 & $5 \%$ \\
\hline 3 & $22 \%$ \\
\hline 4 & $30 \%$ \\
\hline 5 - Strongly Agree & $42 \%$ \\
\hline
\end{tabular}

When asked about the use of printed books as support in distance learning, students showed conservatism, stating that they are fundamental to undertake their studies. It is observed from the chart below that $80 \%$ agree that the book is essential for learning, and only $8 \%$ do not consider critical.

Chart 2. Printed book Need to carry out the course.

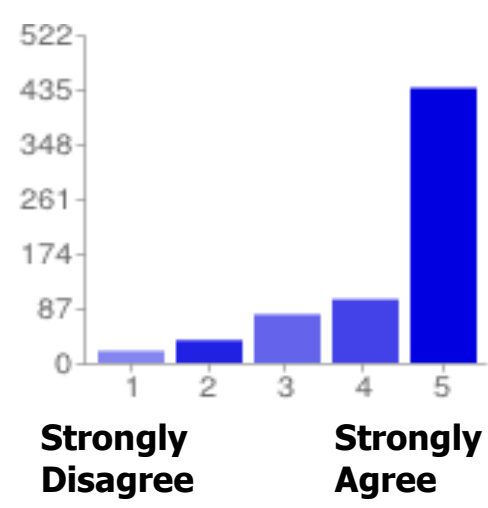

\begin{tabular}{|l|c|}
\hline 1 - Strongly Disagree & $3 \%$ \\
\hline 2 & $5 \%$ \\
\hline 3 & $11 \%$ \\
\hline 4 & $15 \%$ \\
\hline 5 - Strongly Agree & $65 \%$ \\
\hline
\end{tabular}

Such conservatism is opposed, however, the results presented in Figure 2, which shows the results of the question on whether they would accept receiving a mobile device to replace books. It was found that $58 \%$ agree to the change, and only $26 \%$ of respondents did not agree to such a change.

This result may have a bias of interest outside the exchange itself, but the fact that the mobile device - tablet, could be used in addition to the study; therefore the results cannot express the reality. However, we must consider that $26 \%$ of respondents are in the age groups higher course, i.e. $\mathbf{4 5 \%}$ of students over $\mathbf{4 0}$ years old, a generation known as "digital migrants", i.e., they had to adapt over life for the use of technologies, job functions, study and update information.

With regard to the presence, the federal law requires the student's presence during the assessments. Other participations depend on the decisions taken by the offering institution of the course. In the distance education of IFPR graduate course assessments and the board of examiners of the Final Work are prepared individually.

As the acceptance of video classes available in VLE, the result shows that $67 \%$ of respondents believe that they are fundamental to the detriment to other resources such as textbooks, directed activities, case studies, research, tutorials and forum discussions. This demonstrates that teaching is still very rooted in the lecturer teacher paradigm exposing their knowledge and the student absorbing the lessons passively and with little interactivity. This result shows little maturity of the student in the teaching-learning process. 
An activity which is well accepted and considered important to support students is the class content review. At first, the class revision occurred in real time, prior to the presential review, but over time, it began to be recorded and made available in advance by allowing the student to be able to prepare at any time within their availability and organization. The results show that $77 \%$ agree that the preparation for the evaluations is essential, and $76 \%$ of respondents would be satisfied if the class revision was made available in advance at the virtual learning environment (VLE), allowing the review of the content at home and not needing to watch the class live at the presential support location before the evaluation.

\section{Chart 3 - Level of satisfaction with the course methodology.}

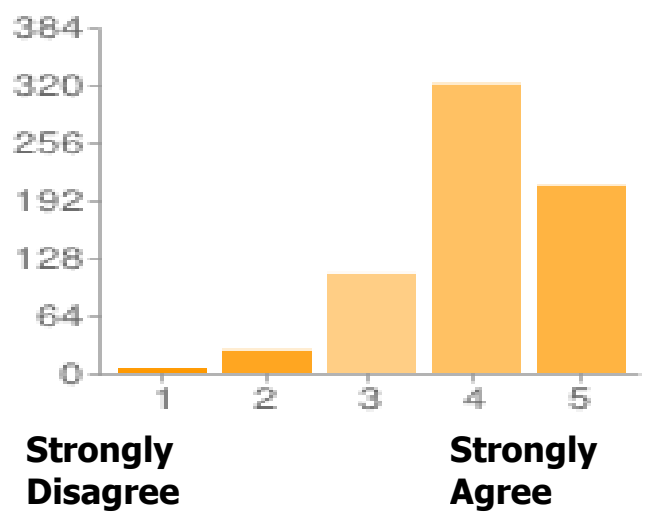

\begin{tabular}{|l|l|}
\hline 1 - Strongly Disagree & $1 \%$ \\
\hline 2 & $4 \%$ \\
\hline 3 & $16 \%$ \\
\hline 4 & $48 \%$ \\
\hline 5 - Strongly Agree & $31 \%$ \\
\hline
\end{tabular}

Out of the 670 respondents, $79 \%$ say they are satisfied in relation to the course methodology, i.e., teaching via internet, using information and communication technologies based on the teaching-learning process, and only $5 \%$ of the respondents showed dissatisfaction with the method.

These results strongly corroborate the study Hairston and Nafukho (2011), which sought to assess the performance difference between the participants in an e-learning course and those enrolled in a traditional classroom course. The results show that although both groups have significantly improved after the training, there were no statistically significant differences in performance between the groups. This result confirms previous studies that do not distinguish learning performance among different modalities, but at the same time calls attention to the distinction between different learning profiles of students.

It is believed that these results are motivating to educational managers, for taking into account the profile of the students, about the age, income and other socioeconomic conditions, they are quite encouraging. Thus, the public sector can implement new formal education programs and/or continuing to train workers of a public sector in several spheres. It is further believed that in the coming generations, taking into account students with higher income and younger age, methodologies for teaching e-learning tend to be better accepted, because it is a generation of people called "digital natives" i.e. the ones who were born in the internet generation. This audience can learn different types of knowledge through e-learning technology without the need for a teacher in person controlling and dictating the rules of the activities to be developed in a school setting.

\section{CONCLUSIONS}

The research shows that surveyees in the study herein are adults, mostly women, with constituted families, with an average income, and are adapted to the methodology of distance education. It is noteworthy that in relation to the familiarity of the respondents with the methodology and are willing to use new technologies, it was evident that $63 \%$ of them already knew the methodology, which may be a reflection of the degree courses offered by IFPR, since most of the respondents were undergraduates in Public Management which were previously offered at the same institution. 
It is evident that the distance education occupies significant space, within the ways of training methods used in the public sector in Brazil, since $49 \%$ reported to have already performed some kind of training in this modality, which means that they can use this methodology for continuing their education, even it's confirmed that there's no differences in terms of performance between presential and distance trainings (Hairston and Nafukho, 2011).

Regarding to adaptation to distance education, the minority - $7 \%$ - indicated difficulty, which leads to a reflection, because only a minority of the states are not fully adapted, while $\mathbf{2 2} \%$ are neutral and $\mathbf{7 2} \%$ are fully adapted.

It is noteworthy that out of the 670 respondents only 49 showed some kind of difficulty, while 621 were adapted, which may represent a shift in paradigm, for people aged 30 to 50 years old, coming from the regular education, are adapting more and more to this methodology. These learning results also can be assigned to the high quality to access the internet. Opposite case was found by the study of Rahardjo, Lubis and Harijati, (2016) where students from rural areas of Indonesia have difficulties to enjoy the educational benefits in function of the barriers to access Internet. On the other hand, the results remain with certain conservatism in relation to teaching materials, as $80 \%$ consider the printed book as a basic material for their studies. However, at the same time, it is clear that the surveys accept to replace the printed book for a tablet, which cannot demonstrate that they in fact, agree to this change, they took into account other aspects such as the product itself and its use in other activities. The data shows the belief that there is openness to change, inasmuch as the 'quality online material might exert a significant effect on students' perceived satisfaction and enhance their learning outcomes (Yueh, Liu \& Liang, 2015:124).

As for the $\mathbf{2 6 \%}$ who disagree can be part of the "digital migrants", i.e. they can be adapted to the use of technology as a result of the need to work, driven by the need to study or search for information. When asked about the web classes and classes revision, most of them understand it as essential to their learning. Regarding the review classes, it is evident that the student needs freedom and must respect their studies schedule.

By watching the revision lessons at home, they have the possibility to better use what you do before the event time in the classroom presential location. Out of the 670 surveyees, $79 \%$ showed a significant positive result and answered they were satisfied with the methodology of the e-learning course and the use of ICT based in the teaching-learning process. $16.4 \%$ of the surveyees had an average perception of the quality of the course and only $4.6 \%$ showed low perception, i.e. dissatisfaction with the course methodology.

Checked that the positive results are encouraging for education managers, as it is evident that the majority of students are satisfied and adapted to the e-learning methodology of distance education. Considering the profile of the students in relation to age, income and other socioeconomic conditions, these results are also significant. Thus, the public sector has the ability to implement new formal education programs and/or continuing to train civil servants in the various spheres, but should take into account the demands and needs of students (Halicki et. al., 2016).

It presents as limitation of this study, the exclusive use of quantitative research to assess the perceived quality and acceptance of e-learning, as well as qualitative research and the combination of different research strategies can enlarge the view of the object of study. Another limitation refers to the level of education (graduate), it is also needed to understand whether it makes the prospects and limitations of e-learning methodology in vocational education and higher education. It is suggested that future research address the training and development of civil servants through different research methodologies and to understand the effectiveness of educational materials (digital and print) for e-learning. Also encourages that researchers investigate the social benefits from the distance learning, especially e-learning for people in remote areas of large cities. 


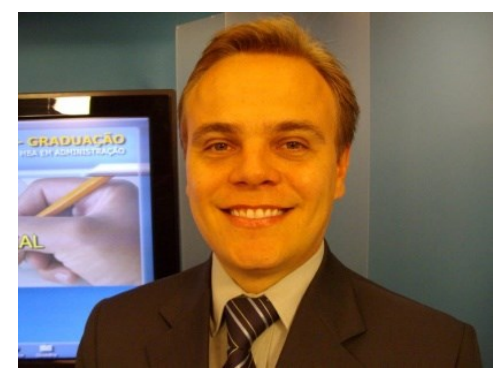

Adriano STADLER is PhD in Business Management and Tourism from University of Vale do Itajai - UNIVALI, with doctoral internship at Glasgow Caledonian University - UK. He holds a Bachelor's degree in Business Management (2000) and a Full Degree in Mathematics from the Federal Technological University of Parana (2002), a Master's degree in Business Management from the University of Vale do Itajai (2007). He is currently a lecturer at a Brazilian public university, "IFPR - Federal Institute of Parana". His publications are in the area of entrepreneurial education, vocational education and distance education.

\section{Adriano STADLER}

IFPR - Federal Institute of Parana, Campus Curitiba

R. Joao Negrao, 1285 - Reboucas, Curitiba - PR, Brazil - Post Code: 80230-150

Phone: +5541-996347323

E-mail: adriano.stadler@ifpr.edu.br

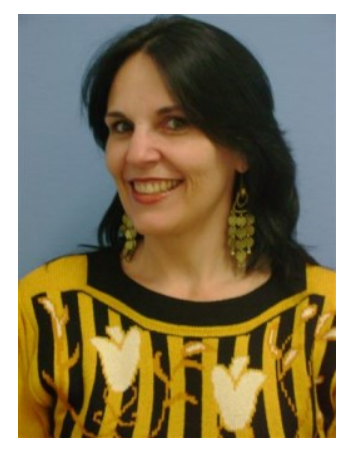

Rosi Teresinha Munaretti de CAMARGO is Master's student in Education and New Technologies with research on Distance Education. She holds a Full Degree in Literature - Portuguese - Spanish. Technologist in Management Processes. Specialization in Distance Education (training of lecturers and counselors) and Relational Psychomotricity and People Management. She is currently General Coordinator of the Vocational Course in Logistics at the Federal Institute of Parana - IFPR.

Rosi Teresinha Munaretti de CAMARgo

IFPR - Federal Institute of Parana, Campus Curitiba

R. Joao Negrao, 1285 - Reboucas, Curitiba - PR, Brazil - Post Code: 80230-150

Phone: +5541-991915668

E-mail: rosi.munaretti@ifpr.edu.br

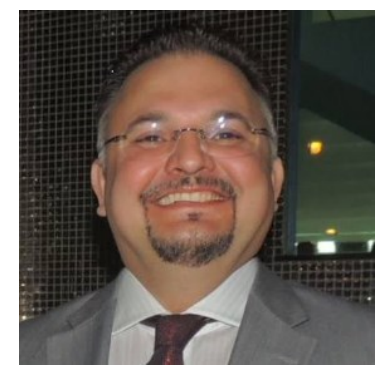

Marcos Rogerio MAIOLI is PhD student in Environmental Management from Positivo University - UP. Master's Degree in Tourism and Hospitality from UNIVALI (2016). Bachelor in Tourism from the Federal University of Parana - UFPR (1997). Specialization in Planning and Management of Tourism and Political Sociology both by UFPR. He is currently lecturer in higher education - Public Management, vocational courses in Events, Logistics, Administration and Distance Education in IFPR - Federal Institute of Parana. Has experience in the area of Tourism and Hospitality, with emphasis on Organization of Events.

\section{Marcos Rogerio MAIOLI}

IFPR - Federal Institute of Parana, Campus Curitiba

R. Joao Negrao, 1285 - Reboucas, Curitiba - PR, Brazil - Post Code: 80230-150

Phone: +5541-996947868

E-mail: marcos.maioli@ifpr.edu.br 


\section{REFERENCES}

ABED - Associacao Brasileira de Educacao a Distancia. (2016) [Brazilian Association of Distance Education] Censo EAD.BR. 2014/2015. Available and on line at: http://www.abed.org.br/site/pt/midiateca/censo_ead/1342/2015/10/ censoead.br_-_2014/2015

Belloni, M.L. (2003) Educacao a Distancia. [Distance Education] 3 ed. Campinas: Autores Associados.

Brasil, (1996). Lei no 9.394, de 20 de dezembro de 1996. Estabelece as diretrizes e bases da educacao nacional. [Establishes the guidelines and bases for national education]. Diario Oficial da Uniao. Brasilia, DF.

Brasil, (2006). Decreto no 5.800, de 08 de junho de 2006. Dispoe sobre o Sistema Universidade Aberta do Brasil-UAB [It provides for the System Open University of Brazil-UAB]. Diario Oficial da Uniao. Brasilia, DF, 9.

Brasil, (2008). Lei no 11.892, de 29 de Dezembro de 2008. Institui a Rede Federal de Educacao Profissional, Cientifica e Tecnologica, cria os Institutos Federais de Educacao, Ciencia e Tecnologia, e da outras providencias. [Law number 11,892 of December 29th 2008 establishing the Federal Professional Education Network, science and technology, creates the Federal Institutes of Education, Science and Technology, and other measures.] Diario Oficial da Republica Federativa do Brasil. Brasilia, DF, 30.

Fernandez, N. R. (2014). Fundamentos del proceso educativo a distancia: ensenanza, aprendizaje yevaluacion [Foundations of the distance education process: teaching, learning and assessment]. Revista Iberoamericana de Educacion a Distancia, 17(2), 75.

Ferreira, A. D. O. (2009). Avaliacao da Qualidade Percebida em cursos de educacao a distancia por meio do e-learning: Aplicacao do SERVQUAL nos programas de MBA do Senac Rio [Perceived Quality Assessment in distance education courses through e-learning: SERVQUAL application in MBA Senac Rio programs] Dissertacao Mestrado Profissionalizante em Administracao. Faculdade de Economia e Financas IBMEC, Rio de Janeiro.

IFPR - Instituto Federal do Parana (2011) Material Orientador para professores-autores [Guidance material for teachers-author] - Coordenacao de Design Instrucional, Instituto Federal do Parana.

Levy, P. A (1998) Inteligencia Coletiva. Por uma antropologia do ciberespaco. [The collective intelligence by a digital anthropology] Sao Paulo: Loyola.

Lima, J. R., \& Capitao, Z. M. A. (2003). e-Learning e e-Conteudos [e-Learning and eContent]. Centro Atlantico.

Preti, 0. (2010) Producao de material didatico impresso: Orientacoes Tecnicas e pedagogicas. [Production of printed educational materials: technical and pedagogical guidance.] Cuiaba: UAB/ UFMT.

Hairston, N., \& Nafukho, F. M. (2011). Determining Statistical Significance between ELearning Training versus Traditional Training in Six Different Industry Settings. International Journal of Vocational Education \& Training, 19(1).

Halicki, Z., Stadler, A., Cunha, S.K., \& Bulgacov, Y.L.M. (2016). A trajetoria tecnologica na educacao a distancia: Inovacoes na pratica docente a partir do metodo Web Based 
Learning em uma instituicao publica federal [The technological trajectory in distance education: innovations in teaching practice from the Web Based Learning method in a federal public institution]. Espacios, 37(10).

Ikeda, A. A., \& Cavalheiro, C. (2005) Reflexoes sobre as Contribuicoes do Ensino a Distancia [Reflections on the contributions of distance education]. e-Gestao Revista Eletronica de Gestao de Negocios, v. 1, n. 3, p. 55-75.

Lavigne, G., Ruiz, G. G., McAnally-Salas, L., \& Sandoval, J. O. (2015). Log Analysis in a Virtual Learning Environment for Engineering Students. Revista de Universidad $y$ Sociedad del Conocimiento, 12(3), 113-128.

Malinovski, T., Vasileva, M., Vasileva-Stojanovska, T., \& Trajkovik, V. (2014). Considering high school students' experience in asynchronous and synchronous distance learning environments: QOE prediction model. The International Review of Research in Open and Distributed Learning, 15(4).

Rahardjo, D., Lubis, D. P., \& Harijati, I. S. (2016). Internet access and usage in improving students'self-directed learning in Indonesia Open University. Turkish Online Journal of Distance Education, 17(2).

Salvucci, M., Lisboa, M. J., \& Mendes, N. C. (2012). Educacao a distancia no Brasil: Fundamentos legais e implementacao [Distance education in Brazil: legal grounds and implementation]. Revista Brasileira de Aprendizagem Aberta a Distancia, Sao Paulo, 11, 49-62.

Vilaca, M. L. C. (2011). Educacao a Distancia e Tecnologias: conceitos, termos e um pouco de historia. (Distance Education and Technology: concepts, terms, and a little history) Revista Magistro, 2(1).

Yin, R. K. (2001). Case Study Research: Design and Methods. California: Sage.

Yueh, H. P., LIU, Y., \& Liang, C. (2015). Impact of Distance Teaching Implementation, Online Material Guidance, and Teaching Effectiveness on Learning Outcomes. International Journal of Engineering Education, 31(1), 121-126.

Welsh, E. T., Wanberg, C. R., Brown, K. G., \& Simmering, M. J. (2003). E-learning: emerging uses, empirical results and future directions. International Journal of Training and Development, $\pi(4)$, 245-258. 